\title{
Environmental protection
} expenditures from the Netherlands in foreign countries

Final report

Statistics Netherlands, December 2011 
Author: Hielke Koppert

Statistisch Onderzoeker,

BNM/ BAD/ Milieu - Den-Haag

kamer: B4061

telefoon: 070-337.4714

email:HKPT@cbs.nI 


\section{Index}

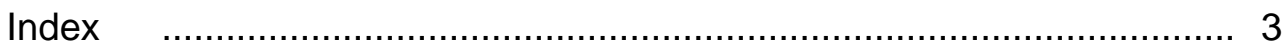

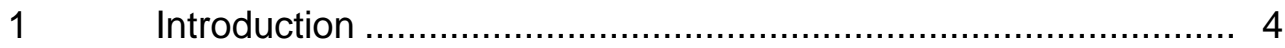

$2 \quad$ Government expenditures abroad........................................... 5

3 HGIS and Policy theme 6: Protected and improved environment 8

$4 \quad$ European environmental policy............................................. 12

$5 \quad$ Conclusion ................................................................. 15

References 
This report deals with the environmental protection expenditures (EPE) of the Netherlands in foreign countries. According to the EPE continuation program granted by Eurostat Statistics Netherlands examines missing sectors that are relevant for understanding environmental policy, spendings and revenues. Although the sector 'foreign countries' is not a sector according to the 'Standaard Bedrijfsindeling' (SBI) (NACE) insight in international environmental expenditures will improve the environmental expenditures statistics and increases the insight in environmental protection and nature conservation measures. The goal is to set up an estimation method for the environmental expenditures the Dutch government make outside the Netherlands. Also European subsidies flowing back to the Netherlands are a point of interest. Environmental expenditures enterprises made abroad are left out of consideration. The year of analysis is 2009 .

Exploring the environmental protection expenditures in foreign countries provides insight in the way the Netherlands is contributing to international environmental policy for example within the framework of the European Union and the United Nations (UN). International policy within the framework of the UN on the environment is related to the broader objective of development assistance. Developed countries strive to support international development goals with $0,7 \%$ of their Gross National Income (GNI) (Arkesteijn, 2010). Within the framework of the EU there are ambitious targets on issues like climate change and biodiversity the Netherlands as net-paying country is contributing to. This report is exploring the way Dutch contributions are used for international environmental purposes and explores the way European funding is used for projects in the Netherlands.

International development assistance from the Dutch government is since 1997 coordinated within the framework 'Homogene Groep Internationale Samenwerking' (HGIS) ('Homogeneous Budget for International Cooperation'). HGIS is a budgetary construction of the central government coordinated by the Ministry of Foreign Affairs (BuZa) and other Ministries as well used for development assistance all over the world mainly developing countries. HGIS with official (ODA) and non-official development assistance (non-ODA) includes environmental expenditures abroad. In particular policy theme 6 under HGIS: Protected and improved environment is examined which also contains expenditures related to international agreements on the subject of climate change.

The institutional reality of the EU becomes more important for the individual Member States on subjects as the environment, nature and biodiversity. Member States of the EU are confronted with environmental policy initiated by the European Commission (EC). Two major topics addressed by the EC are climate change and biodiversity. According to the document 'Financing Biodiversity and Natura 2000' there is an environment related budget within the EU of 46,7 billion (bln) euros in the period 2007-2013 including the $\mathrm{LIFE}+$ programme (EU-Hu, 2011, p.5). On the subject of greenhouse gasses (GHG) and climate change there is a market driven principle introduced with the Emission Trading System (EU ETS). With the introduction of the EU ETS in 2005 the EU took measures to implement Kyoto policy and look beyond the Kyoto agreement ending in 2012. 


\section{Government expenditures abroad}

\section{$2.1 \quad$ Introduction}

The 'Homogene Groep Internationale Samenwerking' (HGIS) ('Homogeneous Budget for International Cooperation') is a budgetary construction in the central government budget of the Netherlands for development assistance abroad including environmental issues. A percentage (approximately 1\%) of the Gross National Income (GNI) each year is reserved for HGIS-spending from which 75\% Official Development Assistance (ODA) and another $25 \%$ is non-ODA spending (BuZa, 2011). In the Netherlands ODA support is about $0,8 \%$ of the GNI (Arkesteijn, 2010).

Environmental issues related to HGIS includes Nature, Environment and Water purposes and also contain transfers to the European Development Fund (EDF), the EU-budget and support for international organisations like the Environment Fund of the United Nations (UNEP). Table 2.1 shows the HGIS related budget for ODA and non-ODA objectives derived from the GNI. Approximately $10 \%$ of HGIS expenditures are reserved for environmental purposes.

Table 2.1: GNI and budgeted development assistance of the Netherlands abroad (mln euros)

\begin{tabular}{|c|c|c|c|c|c|c|}
\hline & Subject & 2001 & 2003 & 2005 & 2007 & 2009 \\
\hline 1 & Gross National Income (GNI) ${ }^{1)}$ & 451.110 & 482.368 & 515.885 & 581.275 & 556.842 \\
\hline 2 & HGIS: Official Development Assistance (ODA) & 3.609 & 3.859 & 4.127 & 4.650 & 4.724 \\
\hline 3 & HGIS: non-ODA expenditures & 1.083 & 1.158 & 1.238 & 1.395 & 1.585 \\
\hline 4 & Environmental expenditures ODA & 397 & 405 & 501 & 615 & 619 \\
\hline 5 & Environmental expenditures non-ODA & 45 & 37 & 50 & 58 & 85 \\
\hline 6 & $\begin{array}{l}\text { (4+5) Total ODA and non-ODA expenditures on } \\
\text { the environment }\end{array}$ & 442 & 441 & 552 & 673 & 704 \\
\hline
\end{tabular}

Source: HGIS-notes

1) Gross National Income (GNI) is used by Statistics Netherlands instead of the GNP (used in HGIS-notes) 


\subsection{HGIS - budgeted and realized expenditures}

Expenditures can be separated in direct and indirect official development assistance (ODA) and non-ODA development assistance. The main difference is that direct ODA is in majority part of coordinated policies of the Ministries themselves, mostly the Ministry of Foreign Affairs (BuZa). Indirect ODA is related to contributions of the Dutch government to governmental and non-governmental international institutions and programmes including the UN and EU. These expenditures are also coordinated by BuZa. Non-ODA assistance is mostly related to other Ministries then BuZa. Non-ODA is used for direct policies, goals or support for example on the subject of climate change or water management.

Table 2.2.1 shows the HGIS budget with direct and indirect ODA expenditures and nonODA expenditures for a total amount of $704 \mathrm{mln}$ euros in 2009. The biggest part $309 \mathrm{mln}$ euros (44\% of $704 \mathrm{mln}$ ) are direct expenditures from different Ministries on nature and environment. Another part is related to indirect expenditures of $310 \mathrm{mln}$ euros (44\%) on tranfers to international institutions and private organisations or programmes. The remaining non-ODA expenditures count for $85 \mathrm{mln}$ euros (12\%) of HGIS expenditures on nature, environment and water.

Table 2.2.1: HGIS - direct and indirect expenditures; nature, environment and water (mln euros)

\begin{tabular}{|c|c|c|c|c|c|c|}
\hline & Subject & 2001 & 2003 & 2005 & 2007 & 2009 \\
\hline 1 & Direct expenditures Nature and Environment & 191 & 178 & 208 & 246 & 309 \\
\hline 2 & Indirect macro support & & & 4 & 16 & 8 \\
\hline 3 & Indirect multilateral & 74 & 88 & 132 & 118 & 74 \\
\hline 4 & Indirect private & 133 & 139 & 133 & 210 & 197 \\
\hline 5 & Indirect other & & & 24 & 26 & 31 \\
\hline 6 & non - ODA & 16 & 23 & 46 & 52 & 82 \\
\hline 7 & non - ODA - Other & 29 & 13 & 4 & 5 & 3 \\
\hline 8 & (1) Total direct ODA expenditures & 191 & 178 & 208 & 246 & 309 \\
\hline 9 & $(2+\ldots+5)$ Total indirect ODA expenditures & 206 & 227 & 293 & 369 & 310 \\
\hline 10 & $(6+7)$ Total non - ODA expenditures & 45 & 37 & 50 & 58 & 85 \\
\hline 11 & $(8+9)$ Total ODA and non-ODA expenditures & 442 & 441 & 552 & 673 & 704 \\
\hline
\end{tabular}

Source: HGIS-notes, for 2007 and 2009 HGIS-note 2009 is used 
In table 2.2.2 the HGIS expenditures for 2007 and 2009 are compared by using HGISnotes over different years. Expenditures differ from year to year. Expenditures on ODA and non-ODA programmes is with $704 \mathrm{mln}$ euros in 2009 16\% less then budgeted (84\% of $837 \mathrm{mln}$ ). The difference between budgeted and realized spending is explained by the fact that programmes are often realized over a longer period of time under responsibility of several Ministries.

Table 2.2.2: Difference between budgeted and realized HGIS expenditures; nature, environment and water (mln euros)

\begin{tabular}{|c|c|c|c|c|c|c|c|}
\hline & Subject & $\begin{array}{l}2007^{1)} \\
\mathrm{A}\end{array}$ & $\begin{array}{l}2007^{2)} \\
\mathrm{B} \\
\end{array}$ & \begin{tabular}{|l}
2007 \\
B/ A (\%)
\end{tabular} & $\begin{array}{l}2009^{2)} \\
\text { C }\end{array}$ & $\begin{array}{l}2009^{3)} \\
\text { D }\end{array}$ & $\begin{array}{l}2009 \\
\text { D/C (\%) }\end{array}$ \\
\hline 1 & Direct expenditures Nature and Environment & 294 & 246 & $83,6 \%$ & 373 & 309 & $82,7 \%$ \\
\hline 2 & Indirect macro support & 17 & 16 & $93,7 \%$ & 13 & 8 & $62,6 \%$ \\
\hline 3 & Indirect multilateral & 110 & 118 & $106,4 \%$ & 122 & 74 & $61,0 \%$ \\
\hline 4 & Indirect private & 160 & 210 & $131,1 \%$ & 195 & 197 & $101,3 \%$ \\
\hline 5 & Indirect other & 27 & 26 & $94,2 \%$ & 30 & 31 & $101,4 \%$ \\
\hline 6 & non - ODA & 82 & 52 & $64,0 \%$ & 102 & 82 & $80,2 \%$ \\
\hline 7 & non - ODA - Other & 4 & 5 & $129,9 \%$ & 3 & 3 & $100,0 \%$ \\
\hline 8 & $(1+\ldots+5)$ Total ODA expenditures & 609 & 615 & $101,0 \%$ & 732 & 619 & $84,5 \%$ \\
\hline 9 & $(6+7)$ Total non - ODA expenditures & 86 & 58 & $67,2 \%$ & 105 & 85 & $80,8 \%$ \\
\hline 10 & $(8+9)$ Total ODA and non-ODA expenditures & 695 & 673 & $96,8 \%$ & 837 & 704 & $84,0 \%$ \\
\hline
\end{tabular}

Source: HGIS-notes 2008, 2009, 2010

1) According to HGIS-note 2008 (over 2007)

2) According to HGIS-note 2009 (over 2007 and 2009)

3) According to HGIS-note 2010 (over 2009)

\subsection{Conclusion}

Expenditures of the Dutch government on the environment abroad are coordinated within HGIS. In HGIS notes contributions of the government under ODA and non-ODA policies are derived as percentage from the GNP. Instead of the GNP Statistics Netherlands uses the GNI (since the introduction of the ESA/ ESR in 1995). The GNP according to the HGIS annual report 2009 is 562,4 bln euros (p.19) the GNI in 2009 is 556,8 bln euros (CBS, 2011) a difference of 5,6 bln euros $(0,9 \%)$. Under HGIS ODA and non-ODA expenditures on the environment are rather stable between $0,09 \%$ and $0,13 \%$ of the GNI over the last 10 years.

The distinction between direct and indirect ODA expenditures under HGIS is made in this report to improve the understanding of the way development assistance is organised in an international context. Direct environmental expenditures are related to Dutch foreign policy and objectives of the Dutch government coordinated by the Ministries themselves (mainly the Ministry of Foreign Affairs). Indirect environmental expenditures are transfers from the Netherlands to organisations and institutions abroad with their own environmental objectives. Non-ODA expenditure under HGIS is related to specific policies coordinated by several Ministries.

The next chapter will elaborate on HGIS-expenditures that are related to environmental policy of Ministries like BuZa, VROM and EZ. 


\section{HGIS and Policy theme 6: Protected and improved environment}

\subsection{Introduction}

Within the HGIS annual reports the realized expenditures on the environment are mentioned under policy theme 6: Better protected and improved environment. Other then in HGIS - notes where reserved or budgeted spending is given annual reports also look at realized spending. In this chapter the budgeted and realized expenditures are compared. Guidance is given by the overview of projects and programmes coordinated by the Ministry of Foreign Affairs (BuZa). The assumption is that expenditures given by BuZa under article 6.1: Environment and 6.2: Water is mostly related to direct ODA expenditures.

The HGIS budget on Nature, Water and Environment is related to direct policies coordinated by several Ministries. The Ministries that are involved are BuZa, the Ministry of Housing, Spatial Planning and the Environment (VROM), the Ministry of Transport, Public Works and Water Management (V\&W), the Ministry of Economic Affairs (EZ) and the Ministry of Agriculture, Nature and Food Quality (LNV). Environmental spending are related to the objectives 'The Millennium Development Goals Closer' and 'An active contribution to new ambitious international climate targets beyond 2012' as stated in HGIS-note 2009 of the Fourth Balkenende cabinet (HGIS, 2009).

Table 2.3 shows the expenditures of the Ministries on environmental issues in 2007 and 2009 according to policy theme 6: Better protected and improved environment. Within this policy theme almost all of the ODA expenditures are for projects from the Ministry of Foreign Affairs. The non-ODA spending are related to the Ministries of VROM, EZ, V\&W and BuZa.

Table 2.3: Policy theme 6: Better protected and improved environment; ODA and Non-ODA budget in 2007 and 2009 (mln euros)

\begin{tabular}{|c|c|c|c|c|c|}
\hline \\
\hline & \multirow[t]{2}{*}{ Subject } & \multicolumn{2}{|l|}{2007} & \multicolumn{2}{|l|}{2009} \\
\hline & & ODA & $\begin{array}{l}\text { non- } \\
\text { ODA }\end{array}$ & ODA & $\begin{array}{l}\text { non- } \\
\text { ODA }\end{array}$ \\
\hline 1 & BuZa & 344,97 & 11,04 & 435,96 & 7,70 \\
\hline 2 & VROM & & 24,95 & & 54,02 \\
\hline 3 & V\&W & 0,03 & 7,45 & 0,03 & 15,40 \\
\hline 4 & EZ & & 11,13 & & 28,70 \\
\hline 5 & LNV & 0,24 & 2,94 & 1,24 & \\
\hline 6 & $(1+\ldots+5)$ Total ODA and non-ODA expenditures per Ministry & 345,2 & 57,5 & 437,2 & 105,8 \\
\hline
\end{tabular}

Source: HGIS-note 2009

The budget for policy theme 6 contains ODA and non-ODA spending of $(437+106=) 543$ $\mathrm{mln}$ euros (HGIS note, 2009, p.23). The assumption is that from the budget of $437 \mathrm{mln}$ euros $373 \mathrm{mln}$ is from direct expenditures (see table 2.2.2) and the other $64 \mathrm{mln}$ euros $(18 \%)$ is from indirect ODA spending, for example the contribution to the United Nations Environment Programme (UNEP). This means that (359-64=) $295 \mathrm{mln}$ euros (82\% of 359 $\mathrm{mln}$ euros) of indirect ODA spending is not included in this policy. Non-ODA spending $105,8 \mathrm{mln}$ euros are almost all related to policy theme 6: better protected and improved environment (p.30). According to the annual report 2009 (385+85=) $471 \mathrm{mln}$ euros (87\% of $543 \mathrm{mln}$ ) of policy theme 6 under HGIS is realized (HGIS annual report, 2009, p.4). 


\subsection{ODA expenditures related to policy theme 6}

For 2009 the expenditures of BuZa under article 6.1: environment and 6.2: water are analysed. The programmes mentioned under these articles are carried out in several developing countries all over the world and contain $329 \mathrm{mln}$ euros which is $74 \%$ of the BuZa budget $(444 \mathrm{mln})$ in 2009. In table 3.1.1 the term, number of projects and total amount of support in 2009 under article 6.1 and 6.2 of BuZa are shown.

Table 3.1.1: Environment and water programmes BuZa (2009)

\begin{tabular}{|r|l|r|r|r|r|r|r|r|r|r|r|r|}
\hline & Projects/ article & 2009 & 2010 & 2011 & 2012 & 2013 & 2014 & 2015 & 2016 & 2017 & Projects & mln euros \\
\hline 1 & 6.1 Environment & 19 & 20 & 97 & 32 & 15 & 8 & 1 & & 1 & 193 & 227,2 \\
\hline 2 & 6.2 Water & 8 & 3 & 40 & 16 & 11 & 5 & 1 & 1 & & 85 & 102,0 \\
\hline 3 & $(2+3)$ Total & 27 & 23 & 137 & 48 & 26 & 13 & 2 & 1 & 1 & 278 & 329,1 \\
\hline
\end{tabular}

Source: Ministry of BuZa (2009)

From 278 projects that are supported 27 ends in 2009. The other projects are to be continued over a longer period of time varying from 2010 till 2017. In the analysis of the programmes under article 6.1 and 6.2 the focus is on the possibility to address different environmental compartments and corresponding expenditures. Table 3.1.2 shows the 10 programmes that are supported the most in 2009.

Table 3.1.2: Programmes under article 6.1 and 6.2 with the most support in 2009

\begin{tabular}{|c|c|c|c|c|}
\hline & Projects/ article & Project & Term & mln euros \\
\hline 1 & 6.1 Environment & Sustainable access to energy & 31-dec-14 & 15,9 \\
\hline 2 & 6.1 Environment & Energy partnership & 31-dec-15 & 15,0 \\
\hline 3 & 6.1 Environment & Environmental support & 31-dec-10 & 12,3 \\
\hline 4 & 6.2 Water & Water, sanitation \& hygiene & 1-jan-12 & 12,2 \\
\hline 5 & 6.1 Environment & CEIF-investment in clean energy & 30-jun-11 & 10,9 \\
\hline 6 & 6.1 Environment & Sustainable energy generation and connections & 31-mei-14 & 10,0 \\
\hline 7 & 6.1 Environment & UNEP 2008-2009 & 30-jun-11 & 9,1 \\
\hline 8 & 6.1 Environment & Disaster Damage Rehabilitation & 30-jun-11 & 7,8 \\
\hline 9 & 6.2 Water & Water Supply System (with ORET) & 31-dec-11 & 7,3 \\
\hline 10 & 6.1 Environment & Natural Resources and Environmental Governance & 31-dec-14 & 7,0 \\
\hline 11 & \multicolumn{3}{|l|}{$(1+\ldots+10)$ total } & 107,4 \\
\hline
\end{tabular}

Source: Ministry of BuZa (2009)

The majority of BuZa spending (75\%) is not attributable to existing environmental compartments used in the environmental protection expenditures statistics of Statistics Netherlands. 48 Programmes and $80,9 \mathrm{mln}$ euros $(25 \%$ of $329 \mathrm{mln})$ of the expenditures in relation to water are divided over art. $6.1(18,6 \mathrm{mln})$ and art. 6.2 . $(62,3 \mathrm{mln})$. Water programmes of BuZa are often related to drinking water and sanitation and not directly to the environment. Other programmes not attributable to existing compartments are energy and biodiversity. They represent $48 \mathrm{mln}$ respectively $16 \mathrm{mln}$ euros. Almost half of the expenditures $134 \mathrm{mln}$ euros $(48 \%$ of $278 \mathrm{mln}$ ) is not attributable to compartments. Other expenditures of BuZa may include education, consultancy and other forms of support. 


\subsection{Non-ODA expenditures related to policy theme 6}

In 2009 climate and energy is mentioned in HGIS as one of the most important issues on the international agenda (HGIS, 2009, p.6). Development expenditures for sustainable energy in relation to climate change and mitigation of greenhouse gasses in developing countries is formulated under objective 6: 'sustainable economical development and fighting poverty'. Direct goals for the Netherlands and Europe are mentioned under objective 8: 'Pro-active effort on sustainability, climate and energy'. According to the annual report of BuZa the objective is the reduction of greenhouse gas emissions and limiting global warming to a maximum of 2 degrees by 2050 compared with pre-industrial values. This objective is also part of the international treaty of Kopenhagen (BuZa, Annual Report, 2009, p.10).

The Kyoto Protocol subscribes three mechanisms: international emission trading, Clean Development Mechanism (CDM) and Joint Implementation (JI) that countries can use to meet their targets for the reduction of greenhouse gas (GHG) emissions. These instruments are implemented on a national level and are created to enhance costeffectiveness emission reduction on places were it is most profitable and stimulate green investments in industries were it is most eligible. According to the Kyoto protocol the Netherlands is obliged to reduce GHG emissions with 6\% in the period 2008-2012 compared with 1990. In this period the Netherlands may emit a maximum of 200 Mton $\mathrm{CO} 2$ equivalents per year on average.

The Dutch government aims to acquire 13 Mton $\mathrm{CO} 2$ eq. emission permits abroad each year in the period 2008-2012 with CDM and JI programmes (CBS, 2010, p.33). CDM and $\mathrm{JI}$ projects are financed with non-ODA expenditures. In the HGIS budget $79 \mathrm{mln}$ euros ( $77 \%$ of $105,8 \mathrm{mln}$ ) is related to climate programmes of the Ministries of VROM and EZ. Almost 67 million euros (85\% of 79 million euros) is realized (BuZa, Annual Report, 2009, p.29). Other non-ODA expenditures are 7,7 mln euros (7,3\%) part of art. $6.1 \mathrm{BuZa}$ and $15,4 \mathrm{mln}$ euros $(14,6 \%)$ of $\mathrm{V} \& \mathrm{~W}$ on the programme Partners for Water. 
For 2009 the realized expenditures on CDM and $\mathrm{Jl}$ are given in table 3.2.1 and 3.2.2. From 54 mln euros budgeted by VROM on CDM 22,2 mln (41\%) euros is realized in 2009. The budget of the Ministrie of $\mathrm{EZ}$ on $\mathrm{JI}(28,7 \mathrm{mln})$ has been exceeded with $15,6 \mathrm{mln}$ euros to $44,3 \mathrm{mln}$ euros. The result is that from CDM and $\mathrm{Jl}$ programmes $66,5 \mathrm{mln}$ euros is realized $(80 \%$ of $82,7 \mathrm{mln})$.

Table 3.2.1: VROM - Clean Development Mechanism (CDM) expenditures in developing countries in 2009 (mln euros)

\begin{tabular}{|r|l|r|}
\hline & & \multicolumn{1}{|c|}{ mIn euros } \\
\hline 1 & CDM: Subsidies/ operational costs and project means & 0,4 \\
\hline 2 & CDM: Purchase of permission rights & 21,8 \\
\hline 3 & $(1+2)$ Total & $\mathbf{2 2 , 2}$ \\
\hline
\end{tabular}

Source: Ministry of VROM (2009), article U430804

Table 3.2.2: EZ - Joint Implementation (JI) expenditures in developed countries in 2009 ( $\mathrm{mln}$ euros)

\begin{tabular}{|r|l|r|}
\hline & & mln euros \\
\hline $\mathbf{1}$ & Jl: subsidies/ AAUPA & 31,8 \\
\hline $\mathbf{2}$ & JI: subsidies/ other & 12,4 \\
\hline $\mathbf{3}$ & $\mathbf{( 1 + 2 )}$ Total & $\mathbf{4 4 , 3}$ \\
\hline
\end{tabular}

Source: Ministry of EZ (2009), article 0420 309/ 310

According to table 3.2.1 and 3.2.2 the expenditures on CDM and $\mathrm{JI}$ contains contributions for operational purposes, subsidies and for purchasing permit rights. Most of the expenditures take place via international institutions like the World Bank.

\subsection{Conclusion}

Policy theme 6: Better protected and improved environment contains direct, indirect ODA spending and non-ODA spending. The assumption is that the total amount of spending under article 6 is containing direct ODA $373 \mathrm{mln}$ euros (68\%), indirect ODA $64 \mathrm{mln}(12 \%)$ and non-ODA expenditures $106 \mathrm{mln}$ euros (20\%). ODA support is related to development goals like a sustainable environment but also fighting poverty and developing a sustainable infrastructure for example sanitation and energy supply.

The Ministry of Foreign Affairs is responsible for almost $100 \%$ of ODA means. The programmes realized by BuZa under article 6.1: Environment and 6.2: Water covers an amount of $329 \mathrm{mln}$ euros. Not all of direct ODA spending according to the HGIS annual report of 2009 can be related to BuZa policy under article 6.1 and 6.2. Another point of attention is that the programmes that are carried out are not directly corresponding with environmental compartments used by Statistics Netherlands. Non-ODA expenditures under CDM (VROM) and $\mathrm{JI}(\mathrm{EZ})$ are related to international agreements and European policy on greenhouse gas emissions. 


\subsection{Introduction}

The main environmental challenges acknowledged by the European Union are climate change and the loss of biodiversity. The reason for mentioning European environmental policy is the assumption that environmental expenditures will increase within the European framework. European policy and legislation on issues as climate change and biodiversity will influence EU-spending, national expenditures and enterprises.

Europe has ambitious targets concerning climate policy following on measures taken under the IPCC framework and Kyoto (CBS, 2010, p.33). In 2010 the Directorate-General for Climate Action is established by the European Commission. The Directorate leads international negotiations on climate change. A concrete measure taken by the $\mathrm{EU}$ is the introduction of the EU Emission Trading System (EU ETS) in 2005. The EU ETS is introduced with the purpose to reduce GHG emissions in 2020 with at least $20 \%$ compared with 1990 and further reductions beyond 2020 (EC, 2011). An example is the (international) transport sector that contributes for $16 \%$ of the Dutch $\mathrm{CO} 2$ emissions but doesn't participate in the EU ETS system yet. The transport sector will be (partly) required to participate in 2012 (CBS, 2010, p.63).

In Europe biodiversity policy is related to the network of protected areas known as Natura 2000. The legal basis for Natura 2000 and the protection of biodiversity comes from the Birds Directive and the Habitats Directive which forms the backbone of the EU's internal biodiversity policy. The biggest environmental expenditures related to Natura 2000 and biodiversity is the acquirement, establishing and management of protected areas. Under Natura 2000750.000 km2 (18\%) of EU's land area is protected. In 27 Member States over 26 thousand areas form the largest protected network in the world built up over the last 25 years (EC 2011). In the period 2007-2013 the total amount of EU funds potentially available for measures of relevance for biodiversity conservation is estimated on 46 billion euros, representing approximately 5,4\% of the EU-budget (EU-Hu, 2011, p.6).

HGIS contributions to the EU contain over $21 \mathrm{mln}$ euros divided over the European Development Fund (EDF) and regular contributions to the EU-budget (HGIS-annual report, 2010, p.35). It is hard to trace the way these contributions are spent for environmental purposes on specific projects because of the lack of transparency and unlabeled contributions. In the next section an estimation method is used instead. The environmental contribution is determined and based on the total contribution of the Netherlands (annex 1) to the EU and the environmental budget of the EU according to the report on financing biodiversity and natura 2000 (EU-Hu, 2011). 


\subsection{Contributions of the Netherlands used for European environmental policy}

Most of the environmental spending by the $\mathrm{EU}$ is based on co-financing of projects initiated in countries of the European Union. Contributions that are used by the EU for environmental purposes are spread over different funds like LIFE+, European Agricultural Fund for Rural Development (EAFRD) and the European Regional Development Fund (ERDF).

To determine the contribution of the Netherlands used for European environmental policy an estimation method based on the total amount of environmental spending according to the overview in the document 'Financing Biodiversity and Natura 2000' and of the LIFE+ programme is used. From an environmental EU budget of 46,7 billion euros in the period $2007-2013$ there is 5,4 bln euros (12\% of $46,7 \mathrm{bln}$ ) related to direct expenditures for biodiversity and Natura 2000 this includes LIFE+ policy with a total amount of 2,1 bln euros.

From the spending not related to direct environmental policy but to indirect or potentially direct environmental policy 29,5 bln euros (63\% of 46,7 bln) is from the EAFRD and $10 \mathrm{bln}$ euros (21\%) from the ERDF. Also the Seventh Framework Programme for Research and Technological Development (FP7) including climate change is not related to direct environmental spending yet (EU-Hu, 2011, p.5). Table 4.1 gives the direct expenditures (co-financing) on biodiversity and Natura 2000 under LIFE+, EAFRD and ERDF funding.

Table 4.1: Direct EU co-financing for biodiversity and Natura 2000, in $\mathrm{mln}$ euros (2007-2013)

\begin{tabular}{|r|l|l|r|}
\hline & Funds & Category & mln euros \\
\hline $\mathbf{1}$ & LIFE+ & Innovation & 472 \\
\hline $\mathbf{2}$ & LIFE+ & Nature, biodiversity & 836 \\
\hline $\mathbf{3}$ & LIFE+ & Other & 836 \\
\hline $\mathbf{4}$ & EAFRD & Natura 2000 payments, agriculture & 483 \\
\hline $\mathbf{5}$ & EAFRD & Natura 2000 payments, forestry & 102 \\
\hline $\mathbf{6}$ & ERDF & Promotion of biodiversity and nature conservation & 2.676 \\
\hline $\mathbf{7}$ & $(\mathbf{1}$ to 6) Total & & $\mathbf{5 . 4 0 3}$ \\
\hline
\end{tabular}

Source: EU-Hu (2011) and LIFE+

To determine the contribution of the Netherlands to EU environmental policy the total contribution of all EU Member States to the EU is used, see annex 1. The Netherlands is with 1,9 bln euros one of the 9 net paying countries in the EU in 2009. The Dutch contribution is $7 \%$ of 27,1 bln euros on net payments (contribution - EU spending) within the EU in 2009. Based on the percentage of $7 \%$ the contribution of the Netherlands on direct EU co-financing for biodiversity and Natura 2000 is $(0,07 * 5,4=) 378 \mathrm{mln}$ euros in the period 2007-2013. For the year 2009 the spending of the EU on direct environmental policy with Dutch contributions to countries that are net receivers is estimated on (378/7=) 54 mln euros. This amount doesn't contain EU environmental spending in the Netherlands itself. For this purpose the LIFE+ programme is examined in the next section. 


\subsection{LIFE+}

The European Commission introduced the LIFE Programme in 1992. LIFE+ is the fourth programme under LIFE with duration of 6 years (2007-2013) in which 2,143 bln euros is spent (by the EU). Projects under LIFE+ can be related to environmental innovation, natural conservation, capacity building and information and communication in all Member States. In the Netherlands 154 projects have been financed since 1992, 124 focus on environmental innovation and 30 on nature conservation. A total investment in the Netherlands of 407 million euros is supported with 102,5 mln euros LIFE spending from the EU under LIFE programme I, II, III and LIFE+ in the period from 1992 till 2010 (Life, 2011).

The LIFE programme provides an overview of EU environmental spending in all of the Member States including the Netherlands see annex 2 Table 4.2 in 2009 shows that 6 projects are co-financed with LIFE+ support in the Netherlands from which 4 projects are related to environmental innovation and 2 projects related to nature. According to the Ministry of LNV the Netherlands will receive on average $8 \mathrm{mln}$ euros per year under LIFE+ (Van Meerlo, 2011).

Table 4.2: EU-LIFE contribution for projects in the Netherlands financed in 2009 (mln euros)

\begin{tabular}{|r|l|l|r|r|}
\hline & Project title & Project numb. & LIFE contr. & \multicolumn{1}{c|}{ Total invest. } \\
\hline $\mathbf{1}$ & QSIDE - Quiet facades and quiet urban areas & ENV/ NL/ 000423 & 0,3 & 0,6 \\
\hline $\mathbf{2}$ & ADIOS - Asbestos denaturing & ENV/ NL/ 000424 & 1,5 & 10,5 \\
\hline $\mathbf{3}$ & BLUETEC - Offshore & ENV/ NL/ 000426 & 2,5 & 8,0 \\
\hline $\mathbf{4}$ & SEWEEX - Sewerage energy exchange & ENV/ NL/ 000427 & 1,3 & 10,0 \\
\hline $\mathbf{5}$ & Revitalising Noordduinen & NAT/ NL/ 000417 & 0,8 & 1,5 \\
\hline $\mathbf{6}$ & Dutch dune revival & NAT/ NL/ 000418 & 3,4 & 6,7 \\
\hline $\mathbf{7}$ & $(\mathbf{1}$ to 6) Total & & $\mathbf{9 , 7}$ & $\mathbf{3 7 , 3}$ \\
\hline
\end{tabular}

Source: http://ec.europa.eu/environment/life/project/Projects/index.cfm?fuseaction=home.search

\subsection{Conclusion}

European environmental policy is related to two main topics climate change and the loss of biodiversity. In 2002 the EU committed itself to the Kyoto agreement which will expire in 2012. The European Commission introduced the EU ETS which will mean a continuation of climate policy for the Member States of the EU. The Natura 2000 network is the centrepiece of EU nature and biodiversity policy. The Netherlands is net payer to the EU and its environmental policy in other European countries for an estimated amount of 54 mln euros in 2009. LIFE+ funding is most clear about how projects on the environment and nature are financed and supported by the EU. The Netherlands received $10 \mathrm{mln}$ euros of co-financing from LIFE+ in 2009. 
Environmental protection expenditures in foreign countries is related to international policy Also goals set by the Dutch government under development assistance. EU environmental policy becomes more important for individual Member States. Climate change and the loss of biodiversity are the major topics within the EU. The European Commission addresses these issues for example with the EU Emissions Trading System (EU ETS) and Natura 2000 policy.

European environmental policy is carried out by the individual Member States and supported with EU funding. Most of the environmental spending within the EU comes with funding for agricultural or regional development supported by the European Agricultural Fund for Rural Development (EAFRD) and the European Regional Development Fund (ERDF). On basis of the total amount of direct EU co-financing on the environment and nature (5,4 bln euros in the period 2007-2013) the contribution of the Netherlands as net EU payer is estimated to be $54 \mathrm{mln}$ euros in 2009. In this report LIFE+ funding is used for determining environmental expenditures of the EU in the Netherlands, 6 projects are cofinanced by EU funding for an amount of almost $10 \mathrm{mln}$ euros (on a total investment of $37,3 \mathrm{mln})$.

The Dutch contribution to EU environmental policy is part of the budgetary construction of the central government 'Homogene Groep Internationale Samenwerking' (HGIS) ('Homogeneous Budget for International Cooperation') coordinated by the Ministry of Foreign Affairs. Total budgeted HGIS-expenditures related to the environment ranges from $0,09 \%$ to $0,13 \%$ of the Gross National Income (GNI) between 2001 and 2009. Under HGIS approximately $0,1 \%$ of the GNI (560 mln euros) is budgeted for the environment, nature and water in 2009. Most of the expenditures are part of direct and indirect Official Development Assistance (ODA) coordinated by the Ministry of Foreign Affairs (BuZa).

Direct ODA spending under Policy theme 6: Better protected and improved environment is (allmost all) related to policy of BuZa. The analysis of data provided by BuZa shows that 278 projects are supported in 2009 for a total amount of $329 \mathrm{mln}$ euros. Policy theme 6 is divided in article 6.1 Environment supported with $227 \mathrm{mln}$ euros (69\%) and 6.2 Water supported with $102 \mathrm{mln}$ euros (31\%). Non-ODA spending by the government is for over $80 \%$ related to climate policy and the Kyoto agreement (till 2012). Projects under the Clean Development Mechanism (CDM) and Joint Implementation programme (JI) together contribute for $(22+44=) 66 \mathrm{mln}$ euros in 2009. These 'emission permit' expenditures are largely used by the government in developing and developed countries.

Table 5.1 shows the above mentioned spendings on the environment, nature and water according to governmental policy and according to the estimation made for the Dutch contribution to direct EU - funding. Also the revenues $(-10 \mathrm{mln})$ of co-financed projects in the Netherlands under LIFE+ are mentioned. Netto spending of the Dutch Government on environment related issues abroad is estimated on 439,5 mln euros in 2009.

Table 5.1: Environmental expenditures and revenues stemming from Dutch and EU policy of the Netherlands abroad in 2009 (mln euros)

\begin{tabular}{|r|l|r|}
\hline & & \multicolumn{1}{|c|}{ mIn euros } \\
\hline $\mathbf{1}$ & BuZa - Policy theme 6.1: Environment & 227,0 \\
\hline $\mathbf{2}$ & BuZa - Policy theme 6.2: Water & 102,0 \\
\hline $\mathbf{3}$ & VROM - Clean Development Mechanism & 22,2 \\
\hline $\mathbf{4}$ & EZ - Joint Implementation & 44,3 \\
\hline $\mathbf{5}$ & Dutch contribution to direct EU - funding & 54,0 \\
\hline $\mathbf{6}$ & EU - LIFE+ co-financing in the Netherlands & $-10,0$ \\
\hline $\mathbf{7}$ & $(\mathbf{1 + \ldots + 6 )}$ Total & $\mathbf{4 3 9 , 5}$ \\
\hline
\end{tabular}

Source: Table 3.1.1, 3.2.1, 3.2.2 and 4.2 
HGIS is a useful source for statistical purposes because of the way it is presented in notes and annual reports by the government. Because the HGIS budgetary construction exists from 1997 it is possible to make time series till 2009. With the use of external sources as the HGIS notes Statistics Netherlands is depending on choices made by the Ministries. Changing policy changes the programmes under direct ODA policies carried out by Ministries. An example is the policy of BuZa with the distinction between ODA programmes under article 6.1: Environment and 6.2: Water. These programmes started in the year 2000 with only a few projects and now contain spending of $329 \mathrm{mln}$ euros on 278 projects. The motive for spending under direct ODA is development assistance which means multiple purposes like poverty reduction, economical development and the environment. This also means that definitions that are used by the Ministries are not by definition according to the definitions of Statistics Netherlands. The Rutte - cabinet decided in 2011 that expenditure on the environment under policy theme 6: Protected and improved environment will no longer be specified within HGIS annual reports (HGIS Annual report, 2010, p.33).

In the elaboration of international environmental spending it has been proven that it is not always possible to make a distinction between environmental, water, nature and biodiversity purposes because no clear definitions or leading motives are used or given. Further research is needed to determine which direct ODA expenditures can be classified into environmental compartments used by Statistics Netherlands. From indirect ODA expenditures the international institutions and programmes can be further examined to determine what their contribution to the environment is. Especially the Dutch contribution to EU environmental policy and EU spending in the Netherlands under LIFE+ and funding like EARDF and ERDF on nature and biodiversity can be elaborated further. A strong recommendation is to examine environmental policy and expenditures within the EU framework. On the most important environmental issues, climate change and biodiversity, the EU leads the way, recently demonstrated by the Durban Climate Change Conference (COP17). 


\section{Annex 1}

EU - budget, contributions and expenditures per country in mln euros (2009)

\begin{tabular}{|c|c|c|c|c|c|}
\hline & Contributions per Member State & 1 & 2 & 3 & 4 \\
\hline 1 & Belgium/ België & 5.629 & 3.238 & -2.391 & $-8,81 \%$ \\
\hline 2 & Bulgaria/ Bulgarije & 979 & 337 & -642 & $-2,36 \%$ \\
\hline 3 & Czech Republic/ Tsjechië & 2.949 & 1.207 & -1.741 & $-6,42 \%$ \\
\hline 4 & Denmark/ Denemarken & 1.328 & 2.208 & 880 & $3,24 \%$ \\
\hline 5 & Germanyl Duitsland & 11.713 & 17.564 & 5.851 & $21,56 \%$ \\
\hline 6 & Estonia/ Estland & 717 & 134 & -582 & $-2,14 \%$ \\
\hline 7 & Ireland/ lerland & 1.378 & 1.357 & -21 & $-0,08 \%$ \\
\hline 8 & Greece (Central) & 5.434 & 2.234 & -3.200 & $-11,79 \%$ \\
\hline 9 & Spain/ Spanje & 11.614 & 10.168 & -1.446 & $-5,33 \%$ \\
\hline 10 & Francel Frankrijk & 13.632 & 18.830 & 5.198 & $19,15 \%$ \\
\hline 11 & Italyl Italië & 9.372 & 13.913 & 4.540 & $16,73 \%$ \\
\hline 12 & Cyprus & 172 & 165 & -7 & $-0,03 \%$ \\
\hline 13 & Latvia/ Letland & 710 & 197 & -513 & $-1,89 \%$ \\
\hline 14 & Lithuania/ Litouwen & 1.790 & 282 & -1.509 & $-5,56 \%$ \\
\hline 15 & Luxembourg/ Luxemburg & 1.453 & 276 & -1.177 & $-4,34 \%$ \\
\hline 16 & Hungaryl Hongarije & 3.569 & 816 & -2.753 & $-10,14 \%$ \\
\hline 17 & Malta & 71 & 55 & -17 & $-0,06 \%$ \\
\hline 18 & Netherlands/ Nederland & 1.850 & 3.760 & 1.911 & $7,04 \%$ \\
\hline 19 & Austria/ Oostenrijk & 1.816 & 2.159 & 343 & $1,26 \%$ \\
\hline 20 & Poland/ Polen & 9.253 & 2.835 & -6.418 & $-23,65 \%$ \\
\hline 21 & Portugal & 3.724 & 1.519 & -2.205 & $-8,12 \%$ \\
\hline 22 & Romania/ Roemenië & 2.951 & 1.218 & -1.733 & $-6,38 \%$ \\
\hline 23 & Slovenia/ Slovenië & 616 & 359 & -258 & $-0,95 \%$ \\
\hline 24 & Slovak Republic/ Slowakije & 1.192 & 628 & -564 & $-2,08 \%$ \\
\hline 25 & Finland & 1.208 & 1.699 & 491 & $1,81 \%$ \\
\hline 26 & Sweden/ Zweden & 1.452 & 2.090 & 638 & $2,35 \%$ \\
\hline 27 & United Kingdom/ Engeland & 6.247 & 13.538 & 7.291 & $26,86 \%$ \\
\hline 28 & EU-total & 102.821 & 102.786 & -35 & $-0,13 \%$ \\
\hline
\end{tabular}

1) Contribution per country to the EU in mln euros (2009)

2) EU contributions per country in mln euros (2009)

3) Netto payment in mln euros (2009)

4) Negative or positive transfer (\%) contributed per country to the EU (2009) 


\section{Annex 2}

Number of projects and expenditures under the LIFE Programme by the EC, period 1992-2010

\begin{tabular}{|c|c|c|c|c|c|c|c|c|c|}
\hline & Projects per Member State & 1 & 2 & 3 & 4 & 5 & 6 & 7 & 8 \\
\hline 1 & Belgium/ België & 84 & 54 & 0 & 1 & 139 & 116,6 & 289,7 & $40,2 \%$ \\
\hline 2 & Bulgaria/ Bulgarije & 1 & 7 & 0 & 0 & 8 & $\mathrm{x}$ & $\mathrm{x}$ & $x$ \\
\hline 3 & Czech Republic/ Tsjechië & 3 & 2 & 0 & 0 & 5 & 5,7 & 10,9 & $52,3 \%$ \\
\hline 4 & Denmark/ Denemarken & 54 & 24 & 0 & 0 & 78 & 79,4 & 193,5 & $41,0 \%$ \\
\hline 5 & Germanyl Duitsland & 187 & 104 & 3 & 3 & 297 & 255,4 & 686,3 & $37,2 \%$ \\
\hline 6 & Estonia/ Estland & 10 & 13 & 3 & 1 & 27 & 12,9 & 27,6 & $46,7 \%$ \\
\hline 7 & Ireland/ lerland & 36 & 16 & 0 & 0 & 52 & 43,4 & 103,7 & $41,9 \%$ \\
\hline 8 & Greece (Central) & 126 & 56 & 0 & 4 & 186 & 122,6 & 236,2 & $51,9 \%$ \\
\hline 9 & Spain/ Spanje & 238 & 205 & 0 & 4 & 447 & 274,9 & 633,4 & $43,4 \%$ \\
\hline 10 & Francel Frankrijk & 183 & 100 & 0 & 1 & 284 & 183,0 & 557,0 & $32,9 \%$ \\
\hline 11 & Italyl Italië & 313 & 215 & 0 & 6 & 534 & 298,7 & 706,1 & $42,3 \%$ \\
\hline 12 & Cyprus & 6 & 3 & 17 & 0 & 26 & 11,6 & 20,4 & $56,9 \%$ \\
\hline 13 & Latvia/ Letland & 11 & 20 & 1 & 0 & 32 & 19,6 & 32,4 & $60,5 \%$ \\
\hline 14 & Lithuania/ Litouwen & 0 & 8 & 1 & 0 & 9 & 7,3 & 12,9 & $56,6 \%$ \\
\hline 15 & Luxembourg/ Luxemburg & 11 & 4 & 0 & 0 & 15 & 15,2 & 45,7 & $33,3 \%$ \\
\hline 16 & Hungaryl Hongarije & 17 & 23 & 0 & 0 & 40 & 33,0 & 62,7 & $52,6 \%$ \\
\hline 17 & Malta & 0 & 1 & 8 & 0 & 9 & 2,8 & 4,6 & $60,9 \%$ \\
\hline 18 & Netherlands/ Nederland & 124 & 30 & 0 & 0 & 154 & 102,5 & 407,1 & $25,2 \%$ \\
\hline 19 & Austrial Oostenrijk & 46 & 40 & 0 & 0 & 86 & 89,0 & 218,5 & $40,7 \%$ \\
\hline 20 & Poland/ Polen & 4 & 15 & 1 & 3 & 23 & 28,7 & 50,4 & $56,9 \%$ \\
\hline 21 & Portugal & 67 & 64 & 0 & 3 & 134 & 64,0 & 116,5 & $54,9 \%$ \\
\hline 22 & Romania/ Roemenië & 16 & 34 & 0 & 1 & 51 & 17,9 & 31,1 & $57,6 \%$ \\
\hline 23 & Slovenia/ Slovenië & 5 & 15 & 2 & 0 & 22 & 14,6 & 27,6 & $52,9 \%$ \\
\hline 24 & Slovak Republic/ Slowakije & 4 & 12 & 0 & 1 & 17 & 14,5 & 29,3 & $49,5 \%$ \\
\hline 25 & Finland & 66 & 51 & 0 & 1 & 118 & 84,3 & 193,1 & $43,7 \%$ \\
\hline 26 & Sweden/ Zweden & 66 & 38 & 0 & 1 & 105 & 115,8 & 286,8 & $40,4 \%$ \\
\hline 27 & United Kingdom/ Engeland & 142 & 51 & 0 & 4 & 197 & 166,4 & 374,4 & $44,4 \%$ \\
\hline 28 & EU-total & 1820 & 1205 & 36 & 34 & 3095 & $2.179,8$ & $5.357,9$ & $40,7 \%$ \\
\hline
\end{tabular}

Source: http://ec.europa.eu/environment/life/countries/index.htm

1) Number of projects on Environmental innovation

2) Number of projects on Nature conservation

3) Number of projects on Capacity building

4) Number of projects on Information and communication

5) Total number of projects

6) Co-financing under EU LIFE+ in the period 1992-2010 in mln euros

7) Total investment in mln euros

8) Co-financing with EU LIFE+ support as \% of total investment 


\section{References}

CBS, (2010). Statistics Netherlands: Environmental accounts of the Netherlands 2009. The Hague/ Heerlen, 2010.

CBS, (2011). Statistics Netherlands:

http://statline.cbs.nl/StatWeb/publication/default.aspx?DM=SLNL\&PA=7343nr\&D1=0-1\%2c56\&D2=0\&D3=101\%2c103\%2c105\%2c107\%2c109\&HDR=G1\%2cT\&STB=G2\&VW=T

EC, (2011). European Commission:

http://ec.europa.eu/environment/enveco/index.htm

http://europa.eu/pol/env/index nl.htm

http://ec.europa.eu/environment/nature/natura2000/

http://europa.eu/legislation summaries/environment/tackling climate change/index $\mathrm{nl} . \mathrm{htm}$

http://ec.europa.eu/clima/policies/roadmap/index en.htm

http://ec.europa.eu/clima/policies/ets/index en.htm

$\underline{\text { http://ec.europa.eu/environment/nature/index en.htm }}$

http://www.europarl.europa.eu/nl/headlines/content/20110630MUN23022/html/Overzicht-van-de-EU-begroting

EU-Hu, (2011). Background paper: Financing Biodiversity and Natura 2000.

Workshop 1: Informal meeting on nature directors 8-9 June, Balatonfüred, Hungary.

Eurostat, (2007). Manual on sourches and methods for the compilation of COFOG Statistics. Classification of the Functions of Government (COFOG).

Life, (2011). European Commission; Environment - LIFE Programme

On the internet: http://ec.europa.eu/environment/life/countries/index.htm

http://ec.europa.eu/environment/life/project/Projects/index.cfm?fuseaction=home. search\&cfid=480550\&cftoken=3e 4fcdb56c049185-92584BB6-CE7D-DD7F-238E6D18FD66336E

Rockström, (2009).

http://blogs.helsinki.fi/consplans/2009/10/09/rockstrom-et-al-2009-a-safe-operating-space-for-humanity-nature$\underline{46472-475 /}$

HGIS, (2011). HGIS Factsheets 2011.

http://www.minbuza.nl/dsresource?objectid=buzabeheer:183544\&type=org

http://www.minbuza.nl/en/The Ministry/Policy and Budget/Homogeneous Budget for International Cooperation

HGIS, (2009). HGIS annual report. Ministry of Foreign Affairs

HR-nr.2, (1999). Nota Homogene Groep Internationale Samenwerking 1999 (HGIS-nota 1999). The Dutch House of Representatives.

HR-nr.2, (2008). Nota Homogene Groep Internationale Samenwerking 2009 (HGIS-nota 2009). The Dutch House of Representatives.

HR-nr.3, (2008). List of questions and answers. Homogene Groep Internationale Samenwerking 2009 (HGIS-nota 2009). The Dutch House of Representatives.

HR-nr.4, (2008). Letter of the Ministers of Foreign Affairs and Development. Homogene Groep Internationale Samenwerking 2009 (HGIS-nota 2009). The Dutch House of Representatives.

Rijksoverheid (2011). http://www.rijksoverheid.nl/onderwerpen/europees-economisch-en-monetairbeleid/begroting-europese-unie 